\title{
Use of a negative binomial distribution to describe the presence of Sphyrion laevigatum in Genypterus blacodes
}

Uso de distribuição binomial negativa para descrever a presença de Sphyrion laevigatum em Genypterus blacodes Patricio Peña-Rehbein ${ }^{1 *}$; Patricio De los Ríos-Escalante²; Raúl Castro ${ }^{3}$; Carolina Navarrete ${ }^{4}$

${ }^{1}$ Escuela de Medicina Veterinaria, Facultad de Recursos Naturales, Universidad Católica de Temuco - UC TEMUCO, Temuco, Chile ${ }^{2}$ Escuela de Ciencias Ambientales, Facultad de Recursos Naturales, Universidad Católica de Temuco - UC TEMUCO, Temuco, Chile ${ }^{3}$ Departamento de Acuicultura, Facultad de Recursos del Mar, Universidad de Antofagasta - UANTOF, Antofagasta, Chile ${ }^{4}$ Independent professional, Temuco, Chile

Received April 192013

Accepted October 12013

\begin{abstract}
This paper describes the frequency and number of Sphyrion laevigatum in the skin of Genypterus blacodes, an important economic resource in Chile. The analysis of a spatial distribution model indicated that the parasites tended to cluster. Variations in the number of parasites per host could be described by a negative binomial distribution. The maximum number of parasites observed per host was two.
\end{abstract}

Keywords: Sphyrion laevigatum, Genypterus blacodes, negative binomial distribution.

\section{Resumo}

Este artigo descreve a frequência e o número de Sphyrion laevigatum da pele de Genypterus blacodes, o qual é um importante recurso econômico no Chile. A análise baseada em modelos de distribuição espacial, demonstrou que os parasitos tendem a ficar agrupados. A variação numérica de parasitas por hospedeiro pode ser descrita por distribuição binomial negativa. O número máximo observado de parasitas por hospedeiro foi dois.

Palavras-chave: Sphyrion laevigatum, Genypterus blacodes, distribuição binomial negativa.

Within the order Ophidiiformes, the genus Genypterus Philippi 1857 contains those species that are most economically important. Three of these species are found in Chilean waters: Genypterus chilensis (Guichenot, 1881), Genypterus maculatus (Tschudi, 1846) and Genypterus blacodes (Forster, 1801), the latter being the most economically significant of the three (CANALES-AGUIRRE et al., 2010). Genypterus blacodes are elongate ell-like fish that are confined to the continental shelf and slope of the southern hemisphere, including the coasts of Australia, New Zealand, Argentina, Uruguay and Chile (CANALES-AGUIRRE et al., 2010; CORDO, 2001; FRANCIS et al., 2002; RIFFO, 1994; WARD; REILLY, 2001). $G$. blacodes is a tertiary predator characterized by a diet that is dominated by demersal and benthic fish (NYEGAARD et al., 2004; RENZI, 1986).

The genus Sphyrion is comprised of three species, Sphyrion laevigatum (Quoy \& Gaimard, 1824), Sphyrion lumpi (Krøyer, $1845)$ and Sphyrion quadricornis Gaevskaya \& Kovaleva, 1984

* Corresponding author: Patricio Peña-Rehbein

Escuela de Medicina Veterinaria, Facultad de Recursos Naturales,

Universidad Católica de Temuco - UC TEMUCO, Manuel Montt, 56,

Casilla 15-D, Temuco, Chile

e-mail: ppenar@uct.cl
(HO, 1992; WALTER; BOXSHALL, 2012). S. lumpi is a common parasite of deep water pelagic fish in the Atlantic Ocean, New Zealand, and the Beaufort Sea (GORDON, 2009; HO; KIM, 1989; MILLER, 2012; WOO, 2006). Other studies have investigated the ecology of S. laevigatum among populations of G. blacodes in New Zealand, Australia, Chile, and Falkland Islands (BRICKLE et al., 2003), but in general, the ecological characteristics of parasitic copepods have been poorly investigated. To date, copepods have been found to be parasitic in less than $2 \%$ of aquatic invertebrates and less than 20\% of fish (MORALES-SERNA; GOMEZ, 2012).

Damage inflicted by Sphyrion spp. is mainly aesthetic, as the parasites leave unsightly scars deep in the flesh of affected fish (PAINE, 1986). Holdfasts that are left behind following parasite death cause abscesses $2 \mathrm{~cm}$ or more in length. In Germany, regulations prohibit the sale of fillets that are more than $5 \%$ affected by the parasite for human consumption, and therefore heavily infected fish are used for fish meal or pet food (WOO, 2006). The aim of this study is to determine the frequency distribution of S. laevigatum on G. blacodes using probabilistic models.

We studied two hundred and nine Genypterus blacodes samples obtained in June and July of 2012 from two marketplaces and one supermarket in Temuco, Chile. Parasites isolated from the skin of 


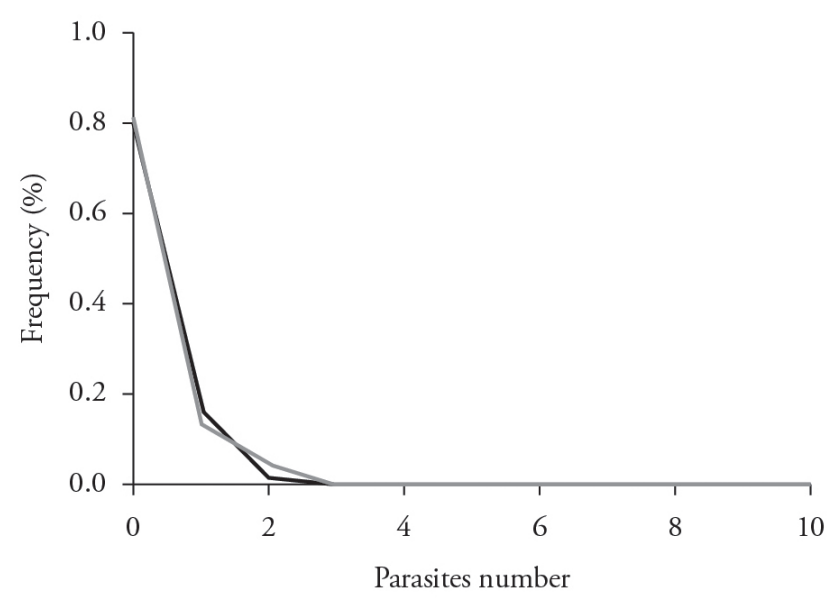

- Expected frecuency — Observed frecuency

Figure 1. Expected and observed frequencies for the negative binomial distribution model describing the presence of Sphyrion laevigatum in the skin of Genypterus blacodes obtained from the fish market of Temuco (Araucanía region, Chile).

Table 1. Numbers of Sphyrion laevigatum parasites observed in the skin of Genypterus blacodes samples obtained from the fish market of Temuco (Araucanía region, Chile).

\begin{tabular}{cc}
\hline $\begin{array}{c}\text { Number of parasites } \\
\text { observed }\end{array}$ & $\begin{array}{c}\text { Number of } \boldsymbol{G} \text {. blacodes } \\
\text { with parasites }\end{array}$ \\
\hline 0 & 171 \\
1 & 29 \\
2 & 9 \\
3 & 0 \\
4 & 0 \\
5 & 0 \\
6 & 0 \\
7 & 0 \\
8 & 0 \\
9 & 0 \\
10 & 0 \\
\hline
\end{tabular}

the fish were fixed in 96\% ethyl alcohol and stored in properly labeled containers until analysis was performed at the School of Veterinary Medicine, Universidad Católica de Temuco, Chile.

The pattern of randomness in the distribution of the number of parasites per host was investigated (ZAR, 1999). We used the variance/mean ratio and the Morisita index to characterize the data as randomly patterned, uniform or clustered (PEÑA-REHBEIN; DE LOS RIOS-ESCALANTE, 2012). Furthermore we applied the Poisson distribution, the negative binomial distribution or the binomial distribution according to the data pattern observed. We used a $\chi^{2}$ test to evaluate the fit of the data to the expected distribution (FERNANDES et al., 2003). All analyses were performed with the XLSTAT 5.0 program (Addinsoft, New York, USA).

The values of the variance/mean ratio and the Morisita index were 1.16 and 105.72 respectively. These results showed that the data followed an overdispersed frequency distribution in their hosts.
We therefore used the negative binomial distribution to model the data. The data fit this distribution $\left(\chi^{2}\right.$ Observed $=0.037<\chi^{2}$ table $=28.336 ; p>0.05)$. Many individuals were found not to contain $S$. laevigatum. The maximum observed number of parasites was two per host (Table 1, Figure 1).

Our findings are similar to the results of Peńa-Rehbein and De los Rios-Escalante (2012) who studied the nematode Anisakis in Thyrsites atun. Confirmation of a negative binomial distribution describing the number of parasites per host suggests a robust model that permits an informative interpretation of parasite distribution patterns (SHAW et al., 1998).

This study was funded by the Veterinary Medicine School and Environmental Sciences School of the Universidad Católica de Temuco, Chile.

\section{References}

Brickle P, Buxton NG, Villalon E. Infection of Sphyrion laevigatum (Copepoda: Sphyriidae) on Genypterus blacodes (Pisces: Ophidiidae) from the Falkland Islands, South Atlantic. J Parasitol 2003; 89: 242-244. http:// dx.doi.org/10.1645/0022-3395(2003)089[0242:IOSLCS]2.0.CO;2

Canales-Aguirre CB, Ferrada S, Hernandez CE, Galleguillos R. Population structure and demographic history of Genypterus blacodes using microsatellite loci. Fish Res 2010; 106: 102-106. http://dx.doi. org/10.1016/j.fishres.2010.06.010

Cordo H. Estandarización del esfuerzo de pesca ejercido sobre el Abadejo (Genypterus blacodes) en aguas Argentinas. Periodo 1986-1996. Rev Invest Desarr Pesq 2001; 14: 57-78.

Fernandes MG, Busoli AC, Barbosa JC. Distribuição espacial de Alabama argillacea (Hübner) (Lepidoptera: Noctuidae) em algodoeiro. Neotrop Entomol 2003; 32: 107-115. http://dx.doi.org/10.1590/S1519566X2003000100016

Francis MP, Hurst RJ, McArdle BH, Bagley NW, Anderson OF. New Zealand demersal fish assemblages. Environ Biol Fish 2002; 65: 215-234. http://dx.doi.org/10.1023/A:1020046713411

Gordon D. New Zealand Inventory of Biodiversity. Christchurch: Canterbury University Press; 2009.

Ho JS. Does Sphyrion (Kroyer) (Copepoda: Sphyriidae) occur in the Sea of Japan? With a discussion on the origin and dispersal of Sphyrion Cuvier, 1830. Rep Sado Mar Biol Stat, Niigata Univ 1992; 22: 37-48.

Ho JS, Kim IH. Lophoura (Copepoda: Sphyriidae) parasitic on the rattails (Pisces: Macrouridae) in the Pacific, with note on Sphyrion lumpi from the Sea of Japan. Publ Seto Mar Biol Lab 1989; 34: 37-54.

Miller R. The museum collection database, Fisheries and Oceans Canada digital collections. Quebec: Maurice Lamontagne Institute; 2012.

Morales-Serna FN, Gomez S. Generalidades de los copépodos parásitos de peces en aguas profundas y el caso de Lophoura brevicollum (Siphonostomatoida: Sphyriidae). In: Zamorano P, Hendrickx M, Caso M. Biodiversidad y comunidades del talud continental del Pacifico mexicano. Ciudad de México: Secretaría de Medio Ambiente y Recursos Naturales; 2012.

Nyegaard M, Arkhipkin A, Brickle P. Variation in the diet of Genypterus blacodes (Ophidiidae) around the Falkland Islands. J Fish Biol 2004; 65: 666-682. http://dx.doi.org/10.1111/j.00221112.2004.00476.x 
Paine AIL. Observations on some conspicuous parasites of the South African kingklip Genypterus capensis. S Afr J Mar Sci 1986; 4: 163-168. http://dx.doi.org/10.2989/025776186784461846

Peña-Rehbein P, De los Rios-Escalante P. Use of negative binomial distribution to describe the presence of Anisakis in Thyrsites atun. Rev Bras Parasitol Vet 2012; 21: 78-80. http://dx.doi.org/10.1590/S198429612012000100017

Renzi MA. Aspectos Biologico-pesqueros del Abadejo (Genypterus blacodes). Rev Invest Desarr Pesq 1986; 6: 5-19.

Riffo R. Composición taxonómica y característica cuantitativas de la fauna de parásitos metazoos del congrio dorado Genypterus blacodes Schneider, 1801. Med Amb 1994; 12: 27-31.
Shaw DJ, Grenfell BT, Dobson AP. Patterns of macroparasite aggregation in wildlife host populations. Parasitology 1998; 117: 597-610. http:// dx.doi.org/10.1017/S0031182098003448

Walter TC, Boxshall G. Sphyrion Cuvier, 1830. World Copepoda database [online]. 2012. [cited 2013 Mar 31]. Available from http:// www.marinespecies.org/aphia.php?p=taxdetails\&id=135656

Ward RD, Reilly A. Development of microsatellite loci for population studies of the pink ling, Genypterus blacodes (Teleostei: Ophidiidae). Mol Ecol Notes 2001; 1: 173-175. http://dx.doi.org/10.1046/j.14718278.2001.00066.x

Woo PT. Fish Diseases and Disorders, Volume 1: Protozoan and Metazoan Infections. Cambridge: CABI Publishing; 2006.

Zar JH. Biostatistical analysis. New Yersey: Prentice Hall; 1999. 